\title{
Szkolenia pracowników jako element zarządzania różnorodnością
}

\section{Streszczenie}

W artykule przedstawiono prawne zasady równego traktowania i niedyskryminacji, wskazując również kryteria dyferencjacji w dostępie do szkoleń. Jego celem jest stworzenie typologii szkoleń uwzględniających grupy beneficjentów zróżnicowanych pod względem tożsamości pierwotnej, wtórnej i organizacyjnej oraz przyporządkowanie im przykładowych szkoleń oferowanych na rynku, a także sklasyfikowanie metod i technik szkoleniowych ze względu na różnorodność generacyjną, kwalifikacyjną i style uczenia się. $\mathrm{W}$ artykule omówiono również wybrane projekty szkoleniowe przydatne w realizacji koncepcji zarządzania różnorodnością.

Słowa kluczowe: szkolenie, metody i techniki szkoleniowe, zarządzanie różnorodnością, rozwój kapitału ludzkiego.

Klasyfikacja JEL: M53.

\section{Wprowadzenie}

Szkolenia stanowią istotny instrument rozwoju kapitału ludzkiego w organizacji [Pocztowski 2008, s. 276]. W literaturze przedmiotu wciąż jednak brakuje opisu szkoleń uwzględniających różnorodność tegoż kapitału i oceny ich przydatności w jego kształtowaniu. Podjęcie tej tematyki uzasadnia fakt, że zasoby 
ludzkie organizacji zawsze charakteryzowała pewna niehomogeniczność. Aktualnie heterogeniczność kapitału ludzkiego jest jednak zdecydowanie większa niż wcześniej w wyniku procesów ekonomicznych (globalizacji, wirtualizacji, wzrostu elastyczności przedsiębiorstw) oraz procesów społecznych (starzenia się ludności, indywidualizacji życia, w tym form życia rodzinnego, polaryzacji dochodów i sytuacji życiowej, różnego stopnia radzenia sobie z ryzykiem, które niesie współczesność) [Lipka i Król 2007, s. 16].

W Polsce także mamy coraz częściej do czynienia z osobami z innych kultur, innego pochodzenia etnicznego, co wpływa na zróżnicowanie grona tych, którzy uczestniczą w szkoleniach pracowniczych. Od kilku lat obserwuje się wzrost zatrudnienia cudzoziemców na polskim rynku pracy. W 2015 r. wydano 65789 zezwoleń na pracę cudzoziemca, co stanowiło w stosunku do 2014 r. wzrost o niemal 51\%. Udział obywateli Ukrainy w liczbie osób, którym wydano zezwolenia, jest zdecydowanie największy (ok. 77\%) [Informacja na temat zatrudniania... 2016]. Szacuje się, że w naszym kraju pracuje już ponad milion Ukraińców i przewiduje się ich intensywny napływ w najbliższych latach [Inglot, Kubisiak i Maj 2017]. Zmiany demograficzne zachodzące na rynku pracy związane z procesem starzenia się społeczeństwa sprawiają z kolei, że organizacje są zmuszone do poszukiwania szans wykorzystania potencjału pracowników w dojrzałym wieku.

Sytuacja ta implikuje potrzebę podejmowania działań personalnych zwiększających, zmniejszających bądź utrzymujących na zastanym poziomie różnorodność kapitału ludzkiego. Szkolenia będące instrumentem rozwoju pracowników mogą maksymalizować pozytywne i minimalizować negatywne skutki różnorodności.

Interesująca jest analiza szkoleń uwzględniająca różnorodność kapitału ludzkiego ukierunkowana na uzyskanie odpowiedzi na następujące pytania:

- jakie prawne zasady obowiązują w dostępie do szkoleń uwzględniających różnorodność kapitału ludzkiego?

- jakie można wyróżnić rodzaje ryzyka dyskryminacji i nierówności w obszarze rozwoju kapitału ludzkiego?

- jak kształtuje się heterogeniczność grup beneficjentów szkoleń w kontekście tożsamości pierwotnej, wtórnej i organizacyjnej?

- które metody i techniki szkoleniowe są najbardziej użyteczne dla pracowników różnorodnych generacyjnie, kwalifikacyjnie i o różnorodnym stylu uczenia się?

- które projekty szkoleniowe z praktyki są przydatne w realizacji koncepcji zarządzania różnorodnością?

Celem artykułu jest przedstawienie prawnych zasad równego traktowania i niedyskryminacji w obszarze szkoleń, dokonanie typologii szkoleń uwzględniających grupy beneficjentów zróżnicowanych pod względem tożsamości pierwotnej, wtórnej i organizacyjnej oraz przyporządkowanie im przykładowych 
szkoleń oferowanych na rynku, sklasyfikowanie metod i technik szkoleniowych ze względu na różnorodność generacyjną, kwalifikacyjną i style uczenia się oraz wskazanie projektów szkoleniowych przydatnych w realizacji koncepcji zarządzania różnorodnością.

Na potrzeby artykułu wykorzystano studium literatury przedmiotu, aktów prawnych i przykładów z praktyki oraz ich krytyczną analizę.

\section{Prawne zasady równego traktowania i niedyskryminacji w obszarze szkoleń}

W Polsce powszechne prawo do nauki gwarantuje Konstytucja Rzeczypospolitej Polskiej [1997, art. 70 ust. 1]. Wskazana norma konstytucyjna obejmuje także osoby dorosłe, które chcą podnosić swoje kwalifikacje zawodowe [Skrzydło 2013, s. 77-89]. Obszary i sposoby przeciwdziałania naruszeniom zasady równego traktowania ze względu na płeć, rasę, pochodzenie etniczne, narodowość, religię, wyznanie, światopogląd, niepełnosprawność, wiek, orientację seksualną określa z kolei Ustawa z dnia 3 grudnia 2010 r. o wdrożeniu niektórych przepisów Unii Europejskiej w zakresie równego traktowania.

Podkreślenia wymaga fakt, że kodeks pracy (dalej: k.p. [Ustawa z dnia 26 czerwca 1974 r. ...]) wprowadza zasadę równego traktowania pracowników nie tylko w zakresie warunków zatrudnienia, wynagradzania, ale także dostępu do szkolenia w celu podnoszenia kwalifikacji zawodowych. Zasada równego traktowania i niedyskryminacji została wyrażona $\mathrm{w}$ art. $11^{2} \mathrm{i} 11^{3} \mathrm{k}$.p. i w rozdziale IIa k.p. Przeciwdziałanie dyskryminacji w zatrudnieniu (w tym także w dostępie do szkolenia) stanowi jeden z podstawowych obowiązków pracodawcy wynikający ze stosunku pracy.

Zgodnie $\mathrm{z}$ art. $18^{3 \mathrm{a}} \S 1$ k.p. dostęp do szkolenia w celu podnoszenia kwalifikacji zawodowych powinien być zapewniany zgodnie z zasadą równego traktowania pracowników, bez względu na płeć, wiek, niepełnosprawność, rasę, religię, narodowość, przekonania polityczne, przynależność związkową, pochodzenie etniczne, wyznanie, orientację seksualną, a także bez względu na zatrudnienie na czas określony lub nieokreślony albo w pełnym lub w niepełnym wymiarze czasu pracy. Równe traktowanie oznacza niedyskryminowanie w jakikolwiek sposób, bezpośrednio lub pośrednio (art. $18^{3 a} \S 2$ ).

Zasada równego traktowania ma być respektowana przez pracodawców nie tylko w sytuacji kierowania pracowników na określone szkolenia zawodowe, ale także wtedy, gdy szkolenia zawodowe odbywają się np. z inicjatywy pracownika (zob. art. $103^{1} \S 1$ k.p.; $103^{6} \S 1$ k.p.). Wówczas wyrażenie zgody pracodawcy na podnoszenie kwalifikacji zawodowych pracowników różnicuje ich prawa do 
świadczeń (np. do płatnego urlopu szkoleniowego, zwolnienia z części lub całości dnia z prawem do wynagrodzenia, zwrotu kosztów kształcenia).

Należy zwrócić uwagę, że zróżnicowane sytuacje prawne pracowników podnoszących kwalifikacje zawodowe są dopuszczalne wówczas, gdy są usprawiedliwione uzasadnioną cechą relewantną. Kryterium uzasadnionej dyferencjacji może stanowić: staż pracy pracownika, wyniki w nauce, przydatność szkolenia dla przedmiotu prowadzonej bądź planowanej działalności pracodawcy [Ludera-Ruszel 2016, s. 173-174].

Kodeks pracy zezwala na różnicowanie sytuacji pracowników w zakresie dostępu do szkoleń podnoszących kwalifikacje zawodowe w czterech przypadkach:

- jeżeli jest to obiektywnie uzasadnione ze względu na zgodny z prawem cel, który ma być osiągnięty, a środki służące osiągnięciu tego celu są właściwe i konieczne (art. $18^{3 a} \S 4$ k.p.),

- gdy uzasadniają to obiektywne powody (art. $18^{3 \mathrm{~b}} \S 1$ k.p.),

- gdy odmienne traktowanie pracowników uzasadnia staż pracy (art. $18^{3 \mathrm{~b}} \S 2$ pkt 4 k.p.),

- gdy takie działania są podejmowane przez określony czas i zmierzają do wyrównywania szans wszystkich lub znacznej liczby pracowników wyróżnionych $\mathrm{z}$ jednej lub kilku przyczyn określonych $w$ art. $18^{3 a} \S 1$ k.p. przez zmniejszenie na korzyść takich pracowników faktycznych nierówności (art. $18^{3 \mathrm{~b}} \S 3$ k.p.).

Pracodawca, typując pracowników do udziału w szkoleniu zawodowym i udzielając im określonych świadczeń z tym związanych, może kierować się takimi przesłankami, jak: staż pracy, kwalifikacje pracownika, jego dotychczasowa aktywność w tym zakresie, przydatność szkolenia w wykonywaniu obowiązków pracowniczych na obecnym bądź przyszłym stanowisku pracy, a także potrzeba wzmocnienia pozycji na rynku pracy kobiet, osób młodych, niewykwalifikowanych czy osób niepełnosprawnych czy też wzrost poziomu reprezentacji przedstawicieli tych grup w określonych sektorach, zawodach, na określonych stanowiskach pracy. Te ostatnie działania określane są mianem działań pozytywnych, które mogą być podejmowane w skali makro (przez państwo), jak i w skali mikro (przez pracodawców) (por. [Ludera-Ruszel 2016, s. 83-85]). Szkolenia mogą wtedy stanowić narzędzia aktywnej polityki rynku pracy, wspierające pracowników w trudnej sytuacji, grupy tzw. wysokiego ryzyka [Skórska 2016, s. 102].

\section{Idea równouprawnienia a ryzyko nierówności w obszarze rozwoju kapitału ludzkiego}

Należy zwrócić uwagę, że organizacje mogą tworzyć specjalną politykę szkoleniową dla określonych grup pracowników. W ramach jednego rodzaju działalności 
funkcjonować może wiele programów dostosowanych do różnych grup pracowniczych i kierowniczych. Przykładowo mogą być podgrupy o jednakowych profilach rozwoju, podgrupy zakładające „kurs zwiększonej pomocy” (np. doradztwo w sprawach kariery) lub też podgrupy uwzględniające określony wiek pracowników - w przypadku polityki dotyczącej planów przechodzenia na emeryturę lub dokształcania [Mayo 2002, s. 122].

W obszarze rozwoju kapitału ludzkiego organizacje mogą głosić hasło równouprawnienia, ogólnikowo deklarując brak dyskryminacji albo szczegółowo wymieniając osoby uprzywilejowane. A. Mayo zwraca jednak uwagę, że zasada równouprawnienia jest wprawdzie chwalebna, ale jej stosowanie w praktyce może wiązać się z ryzykiem powstania niepożądanych nierówności. Podkreśla, że prawdziwe równouprawnienie oznacza docenianie różnorodności osób oraz elastyczny sposób zaspokajania ich indywidualnych potrzeb (w tym: szkoleniowych). Przedmiotem zainteresowania kierownika ds. rozwoju zasobów ludzkich powinno być równouprawnienie w dziedzinie kształcenia, w tym także podejście do ustawicznego kształcenia osób, które nie mogą zawrzeć umowy o pracę w pełnym wymiarze czasu lub przebywają na urlopie macierzyńskim (por. [Mayo 2002, s. 133]).

W praktyce pomimo deklaracji równouprawnienia dostrzega się organizacyjne bariery rozwoju pracowników (por. [Rea 2012, s. 243-244]). Do tej grupy barier zalicza się [Miś 2007, s. 128-129]:

- dyskryminację ze względu na płeć - ujawniającą się np. w obszarze możliwości rozwoju organizacji i karier dualnych,

- dyskryminację ze względu na wiek - młodsi pracownicy doświadczają działań dyskryminacyjnych w zakresie selekcji i awansu, starsi w zakresie możliwości rozwoju,

- dyskryminację ze względu na rasę - prawnie zabronioną, ujawniającą się np. w dostępie do edukacji pewnych grup etnicznych,

- inne formy dyskryminacji (np. ze względu na doświadczenie, ukończoną szkołę.

Przykładowo wyniki polskich badań przeprowadzonych w 1037 polskich organizacjach wskazują, że w praktyce pracodawcy stosują częściej strategie dezinwestycji w kapitał ludzki wobec pracowników w dojrzałym wieku, ograniczając koszty pracy i zmieniając strukturę wiekową przez odmłodzenie kadry [Perek-Białas i Turek 2012, s. 101-116].

Jak zauważa A. Hildebrandt, pomimo różnych uregulowań prawnych i ambitnych celów polityki Unii Europejskiej w Europie proces budowania kapitału ludzkiego np. migrantów przez interakcje z lokalną społecznością nie postępuje w stopniu zadowalającym, co wynika nie tylko z ograniczeń instytucjonalnych, ale często z niechęci do mniejszości etnicznych [Hildebrandt 2013, s. 183]. Z. Bauman, 
analizując współczesne zjawisko paniki migracyjnej, podkreśla, że polityka separacji jest rozwiązaniem krótkoterminowym i prędzej czy później Europa będzie musiała znaleźć nowy sposób na wspólne istnienie wielokulturowych i wielonarodowych społeczeństw [Bauman 2016]. Szkolenia mogą stanowić wtedy jedno z narzędzi zarządzania różnorodnością.

\section{Zróżnicowanie beneficjentów szkoleń pod względem tożsamości pierwotnej, wtórnej i organizacyjnej}

Na heterogeniczność beneficjentów szkoleń składają się różnorodne aspekty, które można uporządkować pod względem tożsamości pierwotnej (widocznej), wtórnej (niewidocznej) i organizacyjnej (środowisko pracy) [Jamka 2011, s. 230; Canas i Sondak 2008, s. 9] (por. tabele 1-3). Przyjęty poniżej podział form szkoleń (przykłady z praktyki) uwzględnia kryterium rodzaju uczestników (por. kryteria podziału form kształcenia w pracy [Andrzejczak 2011, s. 81]).

Tabela 1. Heterogeniczność beneficjentów szkoleń uwzględniająca tożsamość pierwotną

\begin{tabular}{|l|l|l|}
\hline \multicolumn{1}{|c|}{$\begin{array}{c}\text { Cechy } \\
\text { (tożsamość pierwotna) }\end{array}$} & \multicolumn{1}{|c|}{$\begin{array}{c}\text { Przykładowi } \\
\text { beneficjenci szkoleń }\end{array}$} & \multicolumn{1}{c|}{ Przykłady z praktyki } \\
\hline Płeć & Kobiety & $\begin{array}{l}\text { „Cross-mentoring dla kobiet” ukierunkowany } \\
\text { na promowanie kobiet na wyższe stanowiska } \\
\text { menedżerskie [Carey 2006] }\end{array}$ \\
\hline Wiek & Młodzież & $\begin{array}{l}\text { „Kursy dla młodocianych pracowników przy- } \\
\text { gotowujące do egzaminów kwalifikacyjnych } \\
\text { i zawodowych”, np. w zawodzie ślusarza } \\
\text { (www.cech.lebork.pl) }\end{array}$ \\
\hline $\begin{array}{l}\text { Sprawność fizyczna, } \\
\text { cechy fizyczne }\end{array}$ & $\begin{array}{l}\text { Osoby } \\
\text { niepełnosprawne }\end{array}$ & $\begin{array}{l}\text { Szkolenia ogólne i specjalistyczne dla pra- } \\
\text { cowników niepełnosprawnych refundowane } \\
\text { ze środków PFRON [Poliwczak 2013]; ,,Bez- } \\
\text { płatne kursy komputerowe dla osób niepełno- } \\
\text { sprawnych” w Centrum Edukacji i Aktywi- } \\
\text { zacji Zawodowej Osób Niepełnosprawnych } \\
\text { (www.wsr.edu.pl) }\end{array}$ \\
\hline $\begin{array}{l}\text { Przynależność etniczna, } \\
\text { rasowa }\end{array}$ & Migranci & $\begin{array}{l}\text { Bezpłatne szkolenia dla cudzoziemców } \\
\text { pn. „Moja firma w Polsce” (www.isp.org.pl) }\end{array}$ \\
\hline
\end{tabular}

Źródło: opracowanie własne na podstawie: [Carey 2006; www.cech.lebork.pl/osrodek-szkolenia-zawodowego/kursy/, data dostępu: 30.01.2017; Poliwczak 2013, s. 85; www.wsr.edu.pl/uczelnia/ biuro-ds-osob-niepelnosprawnych/aktualnosci/1642-nabor-na-bezplatne-kursy-komputerowe-dlaosob-niepelnosprawnych, data dostępu: 30.01.2017; www.isp.org.pl/konferencje,932,501.html, data dostępu: 30.01.2017]. 
Tabela 2. Heterogeniczność beneficjentów szkoleń uwzględniająca tożsamość wtórną

\begin{tabular}{|c|c|c|}
\hline $\begin{array}{c}\text { Cechy } \\
\text { (tożsamość wtórna) }\end{array}$ & $\begin{array}{c}\text { Przykładowi } \\
\text { beneficjenci szkoleń }\end{array}$ & Przykłady z praktyki \\
\hline Wyznanie, religia & $\begin{array}{l}\text { Piloci wycieczek } \\
\text { o różnych wyznaniach } \\
\text { religijnych }\end{array}$ & $\begin{array}{l}\text { Specjalistyczny kurs „Religie świata” dla } \\
\text { pilotów wycieczek, rezydentów i animato- } \\
\text { rów biur podróży (www.turinfo.pl) }\end{array}$ \\
\hline Orientacja seksualna & $\begin{array}{l}\text { Menedżerowie firm, } \\
\text { w których pracownicy } \\
\text { mogą mieć różną orienta- } \\
\text { cję seksualną }\end{array}$ & $\begin{array}{l}\text { Szkolenia dla firm związane z edukacją } \\
\text { seksualną (www.lew-starowicz.pl) }\end{array}$ \\
\hline $\begin{array}{l}\text { Status społeczny } \\
\text { i rodzinny }\end{array}$ & $\begin{array}{l}\text { Właściciele gospodarstw } \\
\text { rolnych w danym woje- } \\
\text { wództwie }\end{array}$ & $\begin{array}{l}\text { Szkolenia w ramach projektów społecznych } \\
\text { na obszarach wiejskich } \\
\text { [Łaguna i Fortuna 2015] }\end{array}$ \\
\hline Kultura & $\begin{array}{l}\text { Ekspatrianci w filiach } \\
\text { międzynarodowych } \\
\text { korporacji w Polsce }\end{array}$ & $\begin{array}{l}\text { Szkolenie międzykulturowe w procesie } \\
\text { adaptacji ekspatriantów [Przytuła 2014]; } \\
\text { szkolenie międzykulturowe The cultural } \\
\text { navigator (www.berlitz.pl) }\end{array}$ \\
\hline $\begin{array}{l}\text { Sytuacja ekonomiczna, } \\
\text { status materialny }\end{array}$ & $\begin{array}{l}\text { Osoby o niskim statusie } \\
\text { materialnym zagrożone } \\
\text { wykluczeniem społecz- } \\
\text { nym }\end{array}$ & $\begin{array}{l}\text { System szkoleń zawodowych dla osób ska- } \\
\text { zanych w ramach projektu „Model zwięk- } \\
\text { szania szans więźniów na zatrudnienie po } \\
\text { zakończeniu odbywania kary oraz zmiana } \\
\text { nastawienia społecznego wobec reintegracji } \\
\text { i zatrudniania” (www.equal.org.pl) }\end{array}$ \\
\hline Wykształcenie & $\begin{array}{l}\text { Osoby o niskich kwalifi- } \\
\text { kacjach }\end{array}$ & $\begin{array}{l}\text { „Obierz nowy kierunek! - aktywizacja } \\
\text { zawodowa osób powyżej } 29 \text { lat o niskich } \\
\text { kwalifikacjach” (www.efs.wup-katowice.pl) }\end{array}$ \\
\hline Styl życia & $\begin{array}{l}\text { Osoby pragnące zacho- } \\
\text { wać równowagę między } \\
\text { życiem zawodowym } \\
\text { a prywatnym }\end{array}$ & $\begin{array}{l}\text { Szkolenie „Work-Life Balance. Jak przywró- } \\
\text { cić i zachować równowagę między życiem } \\
\text { prywatnym a zawodowym” } \\
\text { (www.humanskills.pl) }\end{array}$ \\
\hline Normy i wartości & $\begin{array}{l}\text { Osoby mające problem } \\
\text { z samoakceptacją }\end{array}$ & $\begin{array}{l}\text { Trening myślenia pozytywnego o charak- } \\
\text { terze psychoterapeutycznym [Andrzejczak } \\
\text { 2010] }\end{array}$ \\
\hline Zainteresowania & $\begin{array}{l}\text { Osoby zainteresowane } \\
\text { tematyką dronów }\end{array}$ & $\begin{array}{l}\text { Szkolenie specjalistów z branży bezzałogo- } \\
\text { wego lotnictwa „Licencja na drona” } \\
\text { (www.uslugirozwojowe.parp.gov.pl) }\end{array}$ \\
\hline
\end{tabular}

Źródło: opracowanie własne na podstawie: [www.turinfo.pl/p/og_id,64587,,rainbow_tours,szkolenia,religie_swiata_specjalistyczny_kurs_dla_pilotow.html, data dostępu: 25.01.2017; www.lew-starowicz.pl/oferta/szkolenia/szkolenia-dla-firm, data dostępu: 25.01.2017; Łaguna i Fortuna 2015, s. 20; Przytuła 2014, s. 181; www.berlitz.pl/szkolenia-miedzykulturowe, data dostępu: 30.01.2017; www. equal.org.pl/baza.php?M=16\&PID=29\&SPID=22\&lang=pl, data dostępu: 30.01.2017; www.efs. wup-katowice.pl/__data/assets/pdf_file/0020/12296/7.1.3-2015-27-pazdziernika.pdf, data dostępu: 30.01.2017; www.humanskills.pl/szkolenia-warszawa/kompetencje-miekkie/work-life-balance/, data dostępu: 25.01.2017; Andrzejczak 2010, s. 74; www.uslugirozwojowe.parp.gov.pl/uslugi/view?id $=33335$, data dostępu:30.01.2017]. 
Tabela 3. Heterogeniczność beneficjentów szkoleń uwzględniająca tożsamość organizacyjną

\begin{tabular}{|l|l|l|}
\hline \multicolumn{1}{|c|}{$\begin{array}{c}\text { Cechy (tożsamość } \\
\text { organizacyjna) }\end{array}$} & \multicolumn{1}{|c|}{$\begin{array}{c}\text { Przykładowi } \\
\text { beneficjenci szkoleń }\end{array}$} & \multicolumn{1}{|c|}{ Przykłady z praktyki } \\
\hline Zajmowane stanowisko & $\begin{array}{l}\text { Pracownicy samorzą- } \\
\text { dowi, członkowie korpusu } \\
\text { służby cywilnej, } \\
\text { nauczyciele akademiccy, } \\
\text { pracownicy odbywający } \\
\text { aplikację radcowską } \\
\text { [Poliwczak 2013] }\end{array}$ & $\begin{array}{l}\text { „Zamówienia publiczne dla początku- } \\
\text { jących”- warsztaty dla pracowników } \\
\text { wydziałów publicznych w jednostkach } \\
\text { samorządu terytorialnego i administracji } \\
\text { rządowej (www.szkolenia24h.pl) }\end{array}$ \\
\hline $\begin{array}{l}\text { Charakter wykonywanej } \\
\text { pracy (treść i zakres) }\end{array}$ & $\begin{array}{l}\text { Pracownicy produkcyjni } \\
\text { [Suchy 2010] }\end{array}$ & $\begin{array}{l}\text { „Szkolenia dla pracowników produkcji. } \\
\text { Szkolenia dla przemysłu” } \\
\text { (www.trenerzy.pl) }\end{array}$ \\
\hline $\begin{array}{l}\text { Przynależność } \\
\text { do organizacji }\end{array}$ & $\begin{array}{l}\text { Pracownicy małych } \\
\text { i średnich przedsiębiorstw }\end{array}$ & $\begin{array}{l}\text { Szkolenia biznesowe dla pracowników } \\
\text { sektora MŚP, np.: ,Zarządzanie jakością } \\
\text { w MŚP” (www.akademiaparp.gov.pl) }\end{array}$ \\
\hline Branża & $\begin{array}{l}\text { Lekarze - specjaliści } \\
\text { ortopedii, rehabilitacji, } \\
\text { radiologii, medycyny } \\
\text { sportowej i rodzinnej }\end{array}$ & $\begin{array}{l}\text { „Diagnostyka obrazowa (RTG, USG, } \\
\text { MR, TK) kręgosłupa i kończyn” } \\
\text { (www.inwestycjawkadry.pl) }\end{array}$ \\
\hline
\end{tabular}

Źródło: opracowanie własne na podstawie: [Poliwczak 2013, s. 67; www.szkolenia24h.pl/oferta/ zamowienia-publiczne-dla-poczatkujacych-2-dniowe-warsztaty-praktyczne-kompendium-obowia zujacych/79335,258443/, data dostępu: 30.01.2017; Suchy 2010, s. 42; www.trenerzy.pl/szkolenia-dla-produkcji/, data dostępu: 30.01.2017; www.akademiaparp.gov.pl/szkolenia-biznesowe.html, data dostępu: 30.01.2017; www.inwestycjawkadry.pl, data dostępu: 18.01.2017].

Grupy beneficjentów usług szkoleniowych mogą być zróżnicowane m.in. pod względem wieku, poziomu wiedzy i doświadczenia, a także motywacji do nauki. Przykładowo wśród uczących się dorosłych można wyróżnić następujące grupy: ludzie o bardzo niskich kwalifikacjach, ponownie podejmujący naukę po okresie przerwy, profesjonaliści podejmujący naukę w celu poprawy własnej sytuacji zawodowej, osoby w wieku powyżej 60 lat uczący się dobrowolnie dla własnej przyjemności i rozwoju [Smith 1984]. W niniejszym artykule, omawiając metody i techniki szkoleniowe, uwzględniono różnorodność generacyjną, kwalifikacyjną i odmienne style uczenia się.

\section{Metody i techniki szkoleniowe użyteczne w szkoleniu pracowników reprezentujących różne pokolenia}

Obecnie w organizacjach pracują przedstawiciele różnych pokoleń [Warwas 2016b, s. 79-92]: baby boomers (ur. 1946-1964), generacji X (ur. 1965-1979), 
generacji Y (ur. 1980-1989), generacji C (ur. 1990- ). W stosunku do nich powinno się różnicować poszczególne narzędzia w ramach funkcji zarządzania kapitałem ludzkim (np. w obszarze szkoleń, doskonalenia i rozwoju).

W szkoleniach osób młodych (np. generacji C i Y) często w ramach procesu adaptacji stosowane są staże pozwalające nowo zatrudnionym pracowników na zdobycie wymaganych umiejętności. W przypadku pracowników tych generacji, z wysokimi kompetencjami cyfrowymi, sprawdzą się także rozwiązania wirtualne, które pozwalają na współtworzenie wiedzy i dzielenie się nią. Mogą oni bez problemu korzystać z takich metod, jak: „pigułki wiedzy i umiejętności”, webquest, webinarium, e-assessment i self-coaching (por. [Chrzanowska 2011, s. 20; Smółka 2012, s. 72-75]).

Pracownicy reprezentujący generację $\mathrm{C}$ mogą być zmotywowani do rozwoju także przez grywalizację, którą można potraktować jako aktywną metodę nauczania edutainment, łączącą uczenie się z zabawą i rozrywką (por. [Winnicka-Wejs 2015, s. 57-80]. W perspektywie nadchodzącej eksplozji robotyki sprawdzą się szkolenia rozwijające kreatywność za pomocą robotów edukacyjnych [Ford 2016, s. 23].

Rozwój pracowników generacji Y powinien się z kolei opierać na rozpoznanych indywidualnych celach życiowych i oczekiwaniach zawodowych. Dla pracowników tej generacji ważny jest długoterminowy plan rozwoju, zwiększanie posiadanych umiejętności, doskonalenie miękkich kompetencji, urozmaicanie zadań i poszerzanie odpowiedzialności. W przypadku pokolenia X sprawdzi się model kształcenia przez całe życie, a dobór technik i metod szkoleniowych powinien uwzględniać długość kariery zawodowej, jak również działania aktywizujące [Warwas 2016b, s. 88].

W procesie szkoleń osób dojrzałych (baby boomers) również można zastosować bogaty wachlarz metod i technik szkoleniowych (por. [Kołodziejczyk-Olczak 2014, s. 119-127]). W dużym stopniu mogą być wykorzystywane metody i techniki umożliwiające międzypokoleniowy transfer wiedzy: coaching, zarządzanie projektami, mentoring. Testy umożliwiają kwantyfikowanie i obiektywizowanie posiadanej wiedzy, a prezentacje (wykłady, miniwykłady, odczyty, prelekcje) pozwalają przyswoić nawet większą partię wiedzy teoretycznej. Z kolei dyskusje kierowane (problemowe, grupowe, pogadanki), analizy studiów przypadków, rotacje umożliwiają dojrzałym pracownikom dzielenie się wiedzą i bogatym doświadczeniem zawodowym (por. [Fortuna 2010]). Odgrywanie ról jest także odpowiednie ze względu na umożliwienie transferu wiedzy i jej odnawianie. Na uwagę zasługuje także modelowanie humorem, żartem i satyrą umożliwiające pracownikom dojrzałym efektywne wykorzystanie kompetencji i zaprezentowanie dystansu wobec wielu sfer życia zawodowego i prywatnego (por. [Tamblyn 2009]). Bardzo dobrze rozwinięte społeczne kompetencje tych pracowników mogą być 
efektywnie wykorzystane także w technikach teatru - eksperymencie i improwizacji (por. [Koppett 2003]). Burza mózgów umożliwi im natomiast czerpanie z doświadczenia innych osób i konfrontację z innymi poglądami. Sprawdzi się także shadowing (,bycie cieniem”), gwarantujący efektywne wykorzystanie kompetencji przez obserwację uczestniczącą i opieranie się na wiedzy utajonej.

Umiarkowane możliwości zastosowania ma natomiast szkolenie w terenie (outdoor) ze względu na potencjalne problemy zdrowotne i trudności kondycyjne, które mogą wystąpić w trakcie wykonywania niektórych zadań (przykładem może być rafting, narciarstwo alpejskie, skoki spadochronowe) [Waściński 2002, s. 176]. Symulacje i demonstracje również są umiarkowanie przydatne w procesie szkolenia pracowników dojrzałych w związku z możliwością pojawienia się zadań wymagających bardzo dobrej sprawności psychofizycznej czy przyjmowania pozycji wymuszonej. W przypadku e-learningu może z kolei wystąpić problem związany z korzystaniem z technologii komputerowej. Ograniczeniem szkoleń opartych na e-learningu mogą być zbyt niskie kompetencje cyfrowe oraz opór wobec nowych metod [Kołodziejczyk-Olczak 2014, s. 123-124].

W szkoleniach wpisujących się w koncepcję zarządzania wiekiem, która wykorzystuje różnice pokoleniowe w celu uzyskania efektu synergii z kooperacji pracowników w różnym wieku, doskonale sprawdzą się dwie metody w dużej mierze opierające się na relacjach mistrz-uczeń: mentoring i shadowing [Jurek 2012, s. 154].

\section{Charakterystyka metod i technik szkoleniowych uwzględniających zróżnicowany poziom kwalifikacji pracowników}

Szkolenia pracownicze mogą uwzględniać również różnorodność kwalifikacyjną (np. wysoki i niski poziom kwalifikacji). Istnieją programy dla osób osiągających ponadprzeciętne wyniki. Jeśli organizacja posiada taki program, musi zdecydować, czy pracownicy zostaną wytypowani do wzięcia w nich udziału, czy też będą mogli składać podania [Mayo 2002, s. 131]. Ważny jest także wybór odpowiednich metod i technik szkoleniowych.

Grupę pracowników o wysokim poziomie kwalifikacji stanowić mogą: pracownicy wysoce efektywni, profesjonaliści, pracownicy wiedzy, pracownicy utalentowani (wymienione grupy pracownicze nie są rozłączne) [Miś 2009, s. 273-281].

Pracownicy wysoce efektywni przez sposób działania i wykorzystanie dostępnych możliwości na stanowisku pracy osiągają najlepsze rezultaty indywidualne zgodnie ze zdefiniowanymi standardami. Dzięki formalnym procesom szkoleniowym zapewnianym przez organizację nabywają wiedzę i umiejętności 
konieczne z punktu widzenia potrzeb firmy. Wiedza ta ma charakter formalny i jest ściśle związana ze strategią w zakresie efektywności.

Profesjonaliści to z kolei osoby o szczególnych umiejętnościach - eksperci w swojej dziedzinie. Gromadzą wiedzę dzięki doświadczeniom, rozszerzając formalnie zdobyte kwalifikacje. W procesie szkoleniowym szczególnie ważny jest dobór treści szkolenia, kładzie się nacisk na wiedzę specjalną i unikatową, precyzyjnie ukierunkowaną, dostępną jedynie osobom o szczególnych kwalifikacjach formalnych i doświadczeniu zawodowym, działającym w specyficznych warunkach. Efektywnymi technikami treningu są w omawianym przypadku te, które pogłębiają umiejętności eksperckie.

Pracowników wiedzy wyróżnia natomiast innowacyjność w posługiwaniu się posiadaną i nabywaną wiedzą. Pracownicy wiedzy doskonalą jawną i ukrytą wiedzę, trenują cechy odpowiedzialne za przyswajanie i kreatywne wykorzystanie posiadanych zasobów wiedzy. Ich rozwój rozpatruje się przez pryzmat wzrastającej wiedzy.

Ostatnią grupę pracowników stanowią tzw. talenty - osoby, które wnoszą do organizacji wyróżniające się kompetencje (potencjał intelektualny, specyficzne zdolności i pewne cechy lub ich konfiguracje). Procesy rozwoju talentów oparte są na elastycznym i zindywidualizowanym stosowaniu dostępnych form edukacyjnych, poprzedzonych szczegółową diagnozą zainteresowanych. Efektywne techniki treningu poszerzają wiedzę i umiejętności wynikające z pasji [Kopeć 2012, s. 197]. Instrumentami wykorzystywanymi w procesie szkolenia i doskonalenia talentów mogą być m.in.: naśladownictwo innych talentów w obszarze umiejętności, postaw i zachowań; treningi twórczości, development center [Kopeć 2014, s. 97-98]. Przydatna może okazać się nowa metoda doskonalenia liderów - tutoring, ukierunkowany w szczególności na pracowników utalentowanych, wyróżniających się i wykazujących się ponadprzeciętnym potencjałem (zob. [Moczydłowska i Kowalewski 2014, s. 165-170]).

Inaczej jest w przypadku pracowników o niskich kwalifikacjach, którzy mają niewielkie aspiracje związane z rozwojem zawodowym i w związku z tym mniejsze potrzeby szkoleniowe. $\mathrm{W}$ porównaniach międzynarodowych przyjmuje się, że są to osoby z wykształceniem niepełnym podstawowym, podstawowym lub gimnazjalnym (według klasyfikacji ISCED). W Polsce w ramach projektu systemowego PARP poszerzono definicję o wykształcenie zasadnicze zawodowe oraz średnie ogólnokształcące, argumentując to tym, że także osoby z takim wykształceniem doświadczają trudności na rynku pracy [Kowalewska i in. 2009, s. 12].

Wśród osób o niskich kwalifikacjach zawodowych zdecydowanie najpopularniejsze są kursy doszkalające w ramach posiadanego już zawodu, rzadziej szkolenia komputerowe i z zakresu sprzedaży. Są one zainteresowane szkoleniami zawodowymi podnoszącymi bardziej ich kompetencje „twarde” niż „miękkie”. 
Potrzeba szkoleń pracowników o niskich kwalifikacjach wynika głównie z konieczności ich stałego podnoszenia, lepszego wykonywania zadań oraz zwiększania wydajności pracy [Kowalewska i in. 2009, s. 93-96]. Wydaje się, że najodpowiedniejsze dla nich mogą być techniki szkolenia na stanowisku pracy (tzw. szkolenia on the job).

\section{Metody i techniki szkoleniowe uwzględniające styl uczenia się}

Szkolenia pracownicze powinny uwzględniać także preferowane style uczenia się. Jak słusznie zauważa M. Łaguna, mając do czynienia ze zróżnicowaną grupą, trzeba różnicować także metody pracy. Szkolenia mogą być projektowane w taki sposób, aby te same treści mogły być nauczane w różny sposób [Łaguna 2008, s. 42-43].

Metody i techniki szkoleniowe dostosowane do różnorodnych sposobów przyswajania wiedzy można wskazać, odwołując się do dwupoziomowego modelu D. Kolba [David Kolb's Learning... 2017]. Na pierwszym poziomie znajdują się typy zachowań osób uczących się: konkretne doświadczenie, refleksyjna obserwacja, abstrakcyjna konceptualizacja, aktywne eksperymentowanie, a na drugim poziomie podstawowe style uczenia się: styl przystosowujący, styl rozproszony, styl jednoznacznie ukierunkowany i styl asymilujący. Można również odwołać się do typologii uczących się P. Honeya i A. Mumforda [1996], która dzieli uczących się na aktywistów / empiryków, analityków / osoby refleksyjne, teoretyków i pragmatyków, oraz do dostępnych w literaturze charakterystyk [Szaban 2011, s. 301-308; Łaguna 2008, s. 38-44; Mobbs 2003].

Aktywiści uczą się najlepiej przez działanie, dlatego dla nich najlepsze są ćwiczenia, gry i symulacje. W ich przypadku sprawdzą się: burza mózgów, rozwiązywanie problemów, grupowa dyskusja, odgrywanie ról, symulacje behawioralne i gry symulacyjne (zob. [Balcerak i Woźniak 2014]). Tradycyjne formy nauczania takie jak wykłady i lektury są dla nich zbyt teoretyczne i w związku z tym mniej użyteczne, dlatego warto je zastąpić metodami aktywizującymi [Silberman 2006, s. 130-157].

Osoby refleksyjne lubią zbierać dane i mieć czas na zastanowienie się nad nimi. Najlepiej uczą się, mogąc obserwować innych ludzi przy pracy, mając możliwość zastanowienia się nad tym, czego się nauczyli, sporządzając analizy i raporty bez presji czasowej. Ich proces uczenia mogą ułatwić: kwestionariusze samooceny i aktywności obserwacyjne (np. study missions) (zob. [Kopijer 2011, s. 86]), nauka przez obserwację, coaching, informacje zwrotne od innych, wywiady. Ważne mogą okazać się dla nich prezentacje różnych perspektyw oraz grupy dyskusyjne umożliwiające komunikację asynchroniczną (z czasem na refleksję). 
Teoretycy najlepiej uczą się, gdy poznają treści stanowiące element większego sytemu, modelu czy teorii, które mogą systematycznie analizować i wyjaśniać. Łatwiej uczą się, znając cele, mając do dyspozycji zadania strukturalizowane i koncepcje oparte na racjonalności i logice. W ich uczeniu utrudnieniem są sytuacje angażujące emocje, o dużym stopniu niepewności i niejasnych regułach. W ich przypadku sprawdza się zastosowanie teorii, modeli, statystyk, historii i cytatów. Metody i techniki szkoleniowe powinny być skoncentrowane na koncepcjach teoretycznych przedstawionych w różny sposób. Bardziej użyteczne mogą być grupy dyskusyjne ułatwiające szczegółową debatę na temat teorii niż seminaria ograniczone w czasie.

Pragmatycy najlepiej uczą się, gdy dostrzegają, że proces uczenia ma bezpośrednie zastosowanie praktyczne. Lubią mieć możliwość wypróbowania rozwiązań, przećwiczenia, uzyskania informacji zwrotnych od eksperta. Może ich także stymulować współzawodnictwo w grupie. W tym przypadku sprawdza się interaktywna nauka oparta na rozwiązywaniu problemów i konkretnych studiach przypadków.

Należy pamiętać, że pracownicy są różni i uczą się na różne sposoby. Pracodawcy w miarę możliwości powinni uwzględniać różnorodne potrzeby w tym zakresie, mając na celu skuteczność i efektywność przedsięwzięć rozwojowych. Zróżnicowanie sposobów nauczania jest istotne także dlatego, że w praktyce szkoleniowej mamy do czynienia raczej z heterogenicznymi niż homogenicznymi grupami słuchaczy o odmiennych stylach uczenia się. Warto to uwzględnić, przygotowując dla nich szkolenia (por. [Kozak i Łaguna 2009, s. 14-21]).

\section{Projekty szkoleniowe przydatne w realizacji koncepcji zarządzania różnorodnością}

Biorąc pod uwagę formy projektów szkoleniowych i sposoby doboru uczestników, szkolenia otwarte wydają się rozwiązaniem koherentnym z koncepcją zarządzania różnorodnością. W odróżnieniu od szkoleń zamkniętych (tzw. in company) uczestnikami mogą być pracownicy różnych firm, co zapewnia wymianę doświadczeń z różnych branż w kontekście danego zagadnienia. Ten typ szkolenia umożliwia stworzenie heterogenicznej grupy szkoleniowej [Kopijer 2011, s. 83].

W praktyce można spotkać się także z tzw. projektami cross-funkcyjnymi, w których uczestnikami są pracownicy różnych specjalizacji lub zawodów. Celem tych projektów jest stworzenie multidyscyplinarnych zespołów, w których rozwijane są kompetencje współpracy z fachowcami z innych dziedzin oraz innych działów firmy. Projekty takie mogą być przydatne wobec daleko idącej autonomii 
i odrębności oraz braku chęci otwarcia się na wymianę doświadczeń [Kopijer 2011, s. 87].

Aktualnie bardzo popularne są kursy stolarki, gotowania, szycia, ogrodnictwa, które są dobrym pretekstem do wspólnej pracy i budowania więzi np. między różnymi pokoleniami [Czerniawski 2016, s. 80-82]. Co prawda nie można ich zaliczyć do szkoleń pracowniczych, ale trzeba zwrócić uwagę na to, że mogą stanowić potencjalne narzędzie wspomagające zarządzanie różnorodnością.

Od pewnego czasu rozwija się także idea cross-mentoringu polegająca na tym, że w charakterze mentorów zatrudniane są osoby niezwiązane z podopiecznymi żadnymi stosunkami pracy, co umożliwia wymianę różnych doświadczeń i inne spojrzenie na działalność firmy. Cross-mentoring to także relacje międzygeneracyjne - między starszymi mentorami i młodszymi adeptami określonej działalności [Szaban 2011, s. 212-213].

Szkolenia pracowników z wykorzystaniem outsourcingu mogą być także użyteczne w realizacji koncepcji zarządzania różnorodnością, sprawdzają się m.in. w sektorze nowoczesnych usług charakteryzującym się m.in. multikulturowym kapitałem ludzkim (por. [Listwan i Sierpowski 2016, s. 27-51]).

Programy i szkolenia dotyczące wiedzy na temat różnic, przyswajania umiejętności funkcjonowania i współpracy w heterogenicznych zespołach mogą być jedną z form doceniania różnorodności i przeciwdziałania jej negatywnym skutkom w organizacjach. Szkolenia takie mogą zapobiegać konfliktom, pozwalając uniknąć kosztów procesów sądowych z powodu dyskryminacji. Dzięki szkoleniom zwiększa się świadomość różnorodności i poprawiają się relacje interpersonalne [Waszczak 2009, s. 83-84].

Przy projektowaniu szkoleń firmowych na temat zarządzania różnorodnością można odwołać się do dobrych praktyk warsztatów dla liderów, warsztatów informacyjnych dla pracowników czy też spotkań strategicznych (zob. [Antidiscrimination and Diversity Training... 2007]).

Wszystkie wyżej wymienione projekty szkoleniowe można określić mianem inwestycji we wzrost różnorodności kapitału ludzkiego, które umożliwiają zbliżenie się do optymalnego dla organizacji stopnia heterogeniczności (zob. [Lipka 2010, s. 170-173]).

\section{Wnioski}

Zarządzanie różnorodnością w obszarze szkoleń może wymagać indywidualizacji przedsięwzięć rozwojowych w odniesieniu do określonych grup beneficjentów wyróżnionych z uwagi na cechy tożsamości pierwotnej, wtórnej i organizacyjnej. W tym przypadku inwestycje szkoleniowe uwzględniające hete- 
rogeniczność kapitału ludzkiego mogą wiązać się z różnymi rodzajami ryzyka personalnego, w tym: ryzyka dyskryminacji, nierówności [Lipka 2002, s. 69-75].

Pomimo istniejącego ustawodawstwa $\mathrm{w}$ zakresie równouprawnienia $\mathrm{w}$ obszarze szkoleń, wybór ich uczestników w firmach może być źródłem ryzyka ze względu na różne sposoby ich wyznaczania, np.: „,równe szanse dla wszystkich”, uprzywilejowanie pewnych kategorii pracowników, reguła „wąskich gardeł” (różnicowanie według potencjalnych strat dla organizacji spowodowanych niewypełnieniem luk w profilu zdolności do pracy), faworyzowanie najbardziej uzdolnionych [Lipka 2010, s. 139].

Nie tylko wybór adresatów może nastręczać problemów. Trudnym zadaniem może być także określenie najbardziej użytecznych metod i technik szkoleniowych w kontekście zarządzania różnorodnością [Listwan 2008, s. 356-359]. Ponadto w praktyce firm można zaobserwować stosunkowo niewielką świadomość różnic w podejściu do zarządzania kapitałem ludzkim (np. do szkoleń pracowników w różnym wieku) [Warwas 2016a, s. 71-76].

Analiza wykazała, że ważną przesłanką wzrostu różnorodności i jej znaczenia w organizacjach jest ustawodawstwo dotyczące zasad równego traktowania i niedyskryminacji w miejscu pracy (w tym także w zakresie dostępu do szkoleń), które może przeciwdziałać nierównościom w obszarze rozwoju kapitału ludzkiego.

Biorąc pod uwagę tożsamość pierwotną, wtórną i organizacyjną kapitału ludzkiego, można stworzyć typologię szkoleń uwzględniającą heterogeniczność ich uczestników (beneficjentów) ze względu na: płeć, wiek, sprawność fizyczną, pochodzenie etniczne, wyznanie, orientację seksualną, status społeczny i rodzinny, kulturę, sytuację ekonomiczną, wykształcenie, styl życia, normy i wartości, zainteresowania, zajmowane stanowisko, charakter wykonywanej pracy, przynależność do organizacji, branży.

W szkoleniach pracowników reprezentujących różne pokolenia, różny poziom kwalifikacji i odmienny styl uczenia się można wykorzystywać metody i techniki szkoleniowe dostosowane do ich potrzeb i możliwości rozwojowych. Wśród nich warto wymienić nowe formy, m.in.: grywalizację, robotyzację edukacyjną, tutoring.

Przy projektowaniu programów szkoleniowych powinno się uwzględniać heterogeniczność grup, nie zapominając o procesie transferu uczenia się w organizacji (zob. [Andrzejczak 2011, s. 115-158]). W realizacji koncepcji zarządzania różnorodnością przydatne mogą być szkolenia otwarte, projekty cross-funkcyjne, cross-mentoring, szkolenia z wykorzystaniem outsourcingu czy kursy budujące więzi międzygeneracyjne. 


\section{Literatura}

Andrzejczak A. [2010], Projektowanie i realizacja szkolen, PWE, Warszawa.

Andrzejczak A. [2011], Ekonomizacja szkolenia pracowników jako czynnik wartości przedsiębiorstwa, Wydawnictwo Uniwersytetu Ekonomicznego w Poznaniu, Poznań.

Antidiscrimination and Diversity Training VT/2006/009. Poradnik szkoleniowy. Zarzqdzanie różnorodnościq [2007], http://www.idm-diversity.org/files/EU0708-TrainingManual-pl.pdf (data dostępu: 25.01.2017).

Balcerak A., Woźniak J. [2014], Szkoleniowe metody symulacyjne, Gdańskie Wydawnictwo Psychologiczne, Sopot.

Bauman Z. [2016], Obcy u naszych drzwi, Wydawnictwo Naukowe PWN, Warszawa.

Canas K.A., Sondak K.A. [2008], Opportunities and Challenges of Workplace Diveristy: Theory, Cases and Exercises, Pearson Prentice Hall, New Jersey.

Carey M. [2006], Cross-mentoring: Women on Top, „PaperJam, média économique et financier", Décembre.

Chrzanowska M. [2011], Wirtual w biznesowym Realu - nowe media w edukacji pracowników, „Magazyn Nowoczesna Firma”, wrzesień.

Czerniawski A. [2016], Zbuduj stół i relacje, „Polityka”, nr 34(3073).

David Kolb's Learning Styles Model and Experiental Learning Theory (ELT) [2017], www.businessballs.com (data dostępu: 17.01.2017).

Ford M. [2016], Świt robotów. Czy sztuczna inteligencja pozbawi nas pracy?, Wydawnictwo CDP.pl, Warszawa.

Fortuna P. [2010], Studium przypadku w praktyce szkoleniowej, czyli jak uczyć się na doświadczeniach innych, Gdańskie Wydawnictwo Psychologiczne, Gdańsk.

Hildebrandt A. [2013], Koniec z pracq, Difin, Warszawa.

Honey P., Mumford A. [1996], The Manual of Learning Styles, Peter Honey Publications, Maidenhead.

Informacja na temat zatrudniania cudzoziemców w Polsce [2016], Ministerstwo Rodziny, Pracy i Polityki Społecznej, Departament Rynku Pracy, http://www.mpips.gov.pl (data dostępu: 17.01.2017).

Inglot K., Kubisiak A., Maj S. [2017], Brakuje rąk do pracy. Firmy gorqczkowo poszukuja Ukraińców, http://www.workservice.pl/ (data dostępu: 17.01.2017).

Jamka B. [2011], Czynnik ludzki we współczesnym przedsiębiorstwie: zasób czy kapitał?, Oficyna a Wolters Kluwer Business, Warszawa.

Jurek Ł. [2012], Ekonomia starzejącego się społeczeństwa, Difin, Warszawa.

Kołodziejczyk-Olczak I. [2014], Zarzqdzanie pracownikami w dojrzałym wieku. Wyzwania i problemy, Wydawnictwo Uniwersytetu Łódzkiego, Łódź.

Konstytucja Rzeczypospolitej Polskiej z dnia 2 kwietnia 1997 r., Dz.U. nr 78 poz. 483 z późn. zm.

Kopeć J. [2012], Zarzqdzanie talentami w przedsiębiorstwie, Wydawnictwo Uniwersytetu Ekonomicznego w Krakowie, Kraków.

Kopeć J. [2014], Rozwój talentów [w:] Rozwój zasobów ludzkich organizacji, red. R. Oczkowska, U. Bukowska, Difin, Warszawa.

Kopijer P. [2011], Kompendium zarzqdzania szkoleniami. Praktyczny przewodnik po inwestycjach w rentowność kapitału kompetencyjnego, Wydawnictwo Szkoły Wyższej Psychologii Społecznej „Academica”, Warszawa. 
Koppett K. [2003], Techniki teatru improwizacji w programach szkoleniowych, Oficyna Ekonomiczna, Kraków.

Kowalewska A., Szut J., Mazurek-Kucharska B., Kania I. [2009], Jak inwestować w rozwój pracowników o niskich kwalifikacjach, Polska Agencja Rozwoju Przedsiębiorczości, Wydawnictwo Naukowe Instytutu Technologii Eksploatacji - PIB, Warszawa.

Kozak A., Łaguna M. [2009], Metody prowadzenia szkoleń, Gdańskie Wydawnictwo Psychologiczne, Sopot.

Lipka A. [2002], Ryzyko personalne. Szanse i zagrożenia zarzq̨dzania zasobami ludzkimi, Poltext, Warszawa.

Lipka A. [2010], Inwestycje w kapitał ludzki organizacji w okresie koniunktury i dekoniunktury, Oficyna a Wolters Kluwer Business, Warszawa.

Lipka A., Król M. [2007], Metoda ścieżki krytycznej (CPM) w zarzqdzaniu zasobami ludzkimi, Wydawnictwo Akademii Ekonomicznej w Katowicach, Katowice.

Listwan J. [2008], Szkolenie pracowników [w:] Zarzqdzanie zasobami ludzkimi, red. W. Golnau, CeDeWu, Warszawa.

Listwan T., Sierpowski T. [2016], Szkolenia pracowników z wykorzystaniem outsourcingu [w:] Metody i techniki zarzqdzania zasobami ludzkimi, red. T. Listwan, Ł. Sułkowski, Difin, Warszawa.

Ludera-Ruszel A. [2016], Podnoszenie kwalifikacji zawodowych przez pracowników na gruncie kodeksu pracy oraz wybranych ustaw szczególnych, Wolters Kluwer, Warszawa.

Łaguna M. [2008], Szkolenia, Gdańskie Wydawnictwo Psychologiczne, Gdańsk.

Łaguna M., Fortuna P. [2015], Przygotowanie szkolenia, Gdańskie Wydawnictwo Psychologiczne, Sopot.

Mayo A. [2002], Kształtowanie strategii szkoleń i rozwoju pracowników, Oficyna Ekonomiczna, Kraków.

Miś A. [2007], Koncepcja rozwoju kariery zawodowej w organizacji,Zeszyty Naukowe Uniwersytetu Ekonomicznego w Krakowie, Seria Specjalna: Monografie, nr 183, Kraków.

Miś A. [2009], Retencja i rozwój pracowników o wysokim potencjale [w:] Człowiek i praca $w$ zmieniającej się organizacji, red. M. Gableta, A. Pietroń-Pyszczek, Wydawnictwo Uniwersytetu Ekonomicznego we Wrocławiu, Wrocław.

Mobbs R. [2003], Honey and Mumford Learning Styles, www.le.ac.uk/users/rjm1/etutor/ learningtheories/honeymumford.html (data dostępu: 17.01.2017).

Moczydłowska J.M., Kowalewski K. [2014], Nowe koncepcje zarzqdzania ludźmi, Difin, Warszawa.

Perek-Białas J., Turek K. [2012], Organisation-level Policy Towards Older Workers in Poland, „International Journal of Social Welfare”, vol. 21, https://doi.org/10.1111/ j.1468-2397.2012.00878.x.

Pocztowski A. [2008], Zarzqdzanie zasobami ludzkimi. Strategie - procesy-metody, PWE, Warszawa.

Poliwczak I. [2013], Kształcenie ustawiczne pracowników w Polsce [w:] Instrumenty wspierajace kształcenie ustawiczne pracowników. Regulacje i ich wykorzystanie w podmiotach gospodarczych, red. E. Kryńska, Instytut Pracy i Polityki Społecznej, Warszawa.

Przytuła S. [2014], Zarzq̨dzanie kadrq ekspatriantów $w$ filiach przedsiębiorstw międzynarodowych $w$ Polsce, CeDeWu, Warszawa.

Rea L. [2012], Efektywne szkolenie. Techniki doskonalenia umiejętności trenerskich, Oficyna a Wolters Kluwer Business, Warszawa.

Silberman M. [2006], Metody aktywizujące w szkoleniach, Wolters Kluwer Polska, Kraków. 
Skórska A. [2016], Rynek pracy. Wybrane zagadnienia, Wydawnictwo Uniwersytetu Ekonomicznego w Katowicach, Katowice.

Skrzydło W. [2013], Konstytucja Rzeczypospolitej Polskiej. Komentarz, LEX a Wolters Kluwer Business, Warszawa.

Smith R.M. [1984], Learning How to Learn. Applied Theory for Adults, Open University Press, Milton Keynes.

Smółka P. [2012], Mnożenie korzyści. Zalety programów rozwojowych typu blended, „Personel i Zarządzanie”, nr 1.

Suchy S. [2010], Edukacja dorosłych pracowników i bezrobotnych, Difin, Warszawa.

Szaban J.M. [2011], Zarzqdzanie zasobami ludzkimi w biznesie i administracji publicznej, Difin, Warszawa.

Tamblyn D. [2009], Śmiej się i ucz. 95 sposobów wykorzystania humoru do zwiększenia efektywności nauczania i szkolenia, ABC a Wolters Kluwer Business, Kraków.

Ustawa z dnia 26 czerwca 1974 r. Kodeks pracy, Dz.U. 1974 nr 24 poz. 141, oprac. na podstawie: tj. 2016 poz. 1666, 2138, 2255, 2017 poz. 60.962, www.isap.sejm.gov.pl/ DetailsServlet?id=WDU19740240141 (data dostępu: 28.06.2017).

Ustawa z dnia 3 grudnia 2010 r. o wdrożeniu niektórych przepisów Unii Europejskiej w zakresie równego traktowania, Dz.U. nr 254, poz. 1700.

Warwas I. [2016a], Proces szkoleń - metody i ewaluacja [w:] Warwas I., Rogozińska-Pawełczyk A., Zarzqdzanie zasobami ludzkimi w nowoczesnej organizacji. Aspekty organizacyjne i psychologiczne, Wydawnictwo Uniwersytetu Łódzkiego, Łódź.

Warwas I. [2016b], Zarzqdzanie generacjami na wewnętrznym rynku pracy [w:] Warwas I., Rogozińska-Pawełczyk A., Zarzq̨dzanie zasobami ludzkimi w nowoczesnej organizacji. Aspekty organizacyjne i psychologiczne, Wydawnictwo Uniwersytetu Łódzkiego, Łódź.

Waszczak S. [2009], Postawy wobec różnorodności - uwarunkowania, próba typologii, implikacje [w:] Kulturowe uwarunkowania zarzqdzania kapitałem ludzkim, red. M. Juchnowicz, Oficyna a Wolters Kluwer Business, Kraków.

Waściński T. [2002], Stosowane metody i techniki szkoleń - zastosowanie [w:] Ekonomiczność szkolén pracowniczych. Poradnik menedżera, red. T. Waściński, K. Kiedrowska, Dom Wydawniczy Elipsa, Warszawa.

Winnicka-Wejs A. [2015], Motywowanie do rozwoju z zastosowaniem grywalizacji, „Zarządzanie Zasobami Ludzkimi”, nr 3-4.

\section{Personnel Training as an Element of Diversity Management}

(Abstract)

The paper presents legal principles of equal treatment and non-discrimination, while indicating the criteria for differentiation concerning access to training. Its purpose is to set out a typology of training taking into account groups of beneficiaries which vary in terms of their primary, secondary and organizational identity and then, on that basis, to assign them sample training courses available on the market. It also classifies training methods and techniques for generational diversity, qualifications diversity and learning styles. Finally, the article discusses selected training projects that are useful in the implementation of diversity management.

Keywords: training, training methods and techniques, diversity management, human capital development. 